revista ANTHROPOLÓGICAS

Ano 21, 28(1):279-293, 2017

ENSAIO BIBLIOGRÁFICO

A Look at the Sky of the Wichi

Mauro Mariani ${ }^{\mathrm{a}}$

Cecilia Paula Gómez ${ }^{\mathrm{b}}$

Sixto Giménez Benítez ${ }^{\mathrm{c}}$

\title{
The Wichi and the perception of the sky
}

The Wichi are known as a group of 'hunter-gatherers' who belong to the Mataco-Maká language family together with other ethnic groups such as the Chorote, the Maká and the Nivaclé. At present, they number around 40,000 and are scattered over approximately 100,000 km (Alvarsson 1983, Braunstein 1993). Several asterisms may be traced among Wichi groups and some of them can be named based on the existing bibliography.

Thanks to earlier anthropological work (Braunstein 1976 and 1993) it can be stated that, despite their global denomination and language affinities, the Wichi are not a people with identical characteris-

a Facultad de Ciencias Astronómicas y Geofísicas, Universidad Nacional de la Plata (Argentina). Email: mauro.mariani88@gmail.com.

b Investigadora del Consejo Nacional de Investigaciones Científicas y Técnicas (CONICET), Facultad de Filosofía y Letras. Universidad de Buenos Aires (Argentina). Centro de Investigaciones Históricas y Antropológicas (CIHA). Email: gomezcp@gmail.com.

c Facultad de Ciencias Astronómicas y Geofísicas, Universidad Nacional de la Plata (Argentina). Email: sixto.gimenez.benitez@gmail.com. 
tics. These groups make up an ethnic 'chain' with other communities that exhibit differences in language and traditions.

For the first time, a compilation of this kind is made. We know that, like other indigenous peoples with whom we have worked, the Wichi have their own asterisms, their own reading of the sky, and that it has not disappeared despite their contact with the surrounding society. Furthermore, we know that the Wichi sky gaze was able to adapt to imposed changes without losing its own way of seeing and understanding the cosmos. We consider that this work is essential because, evidently, it is a necessary step for the future research on this subject. This research will provide an account of the diverse celestial perceptions among the Wichi based on the existing literature; it will also consider the myths associated with these perceptions and how these notions are related to fundamental aspects of their culture.

Among Wichi, it is believed that the cosmos is at least divided into three layers, one above the other: the underworld, the earth and the sky. At the same time, in the beginning, the sky was not in the place it is now. In the 1930s, a Wichi called Pedro told Alfred Métraux: "There are two worlds, one above and the other below. Once, the world above our heads was in the place of the earth where we live. But the earth (still further) below did not like to be soiled by the excrement of the people dwelling in the sky and therefore it changed places with the earth above" (Métraux 1939:9). In another version, it was a celestial deity, Nilataj, who created a piece of ground, a circular island over the water that was gradually spread. Furthermore, it was this deity who was disgusted with the excrement of the birds contaminating their land and therefore it inverted the order, placing their sky above the earth (Braunstein 1974). Also, formerly sky and earth were connected by a big tree. The Wichi ancestors were able to climb the tree and go hunting in the world above. Once, some hunters climbed up it and, when reaching the sky, killed a jaguar. They came down, divided the meat, and only gave the offal to an old man. This affront made him so indignant that he burned the tree, thereby avenging 
himself. With no tree left, the hunters could not return and remained marooned in the sky. They currently form an asterism represented by the Pleiades (Métraux 1935) [see below].

The Wichi conceive of the sky as another earth, another place to live, which is also inhabited by 'persons' (Braunstein 1989). The sky, however, is part of the non-Wichi world; its inhabitants are strangers or outsiders as well as powerful beings (Dasso 1989). With regard to the 'persons' or 'spirits' inhabiting the sky, they are known as pulesleley (inhabitants of the sky) and are ahát beings or non-humans. These pulesleley beings are numerous and varied, as they are represented both by different celestial objects (Venus, the stars, the sun, the moon) and by powerful beings like itox pahal, innó pahla, etc. (Califano \& Dasso 1988). These ahat beings are characterised as inhabitants of mythical time. Innó pahla is a protagonist in several Wichi narratives who introduces some changes to the world, like the arrival of domestic animals, and also destroys negative beings. After finishing his task, he leaves his son in charge of keeping peace. The Itox pahal had a human form and were the owners of fire, which came out of their mouth or anus, and they were extremely irritable (Califano \& Dasso 1988).

Hence, the Wichi existence is always linked to the behaviour of these celestial beings and to the relationship established with them. A careful and balanced relationship with these beings is essential to Wichi survival. Any transgressive or neglectful behaviour or treatment towards such powerful beings may result in problems for the community or its members (Barúa 2001). In the early 20th century, Alfred Métraux (1935 and 1939) had already underlined the significance of celestial objects in the Wichi worldview, which was subsequently highlighted by Tomasini (1969/70).

These entities were joined by other characters that were taken from the teachings of the missionaries who reached Wichi territories. Thus, the priests or members of religious orders who die, the angels, God, Jesus Christ, etc., are also regarded as pulesley; they have ahát features and are therefore powerful. Furthermore, several chang- 
es may be observed following the relationship with the different religious denominations arriving in the Chaco region. For instance, the Wichi at Misión Chaqueña 'El Algarrobal' (Salta Province, Argentina) alluded to biblical texts to support or reassert the truth of Wichi myths. This arises when analysing their notion of the 'east side of the world'. This space is seen as the location of the road leading up to the sky - püle. As mentioned earlier, this is where the stars, the sun, the moon, and the spirits introduced by Christianity are found. Thus, the 'east' side would be part of the püle or sky. It should be noted that the sky is described as the layer that extends above the earth and where the asterisms described in Wichi narratives are situated. Hence, the 'east', being part of the sky, designates a space with ahát characteristics (non-human and therefore dangerous and very powerful). As time went by and under the influence of Christianity, these beings became more benevolent and less harmful. However, that part of space is not entirely without danger as it continues to be a place with much power and thus is still considered to be ahat (Dasso 1990). Among the Wichi who live mainly in the villages of Los Baldes and Morillo, in the east of the province of Salta (Argentina), the place where the sun rises, the rising, is called Ijwala-wej (Sun-back), literally meaning: 'hole of the Sun', where the sun rises from the underworld to the sky. On the other hand, the place where the sun goes down, or the west, is called Ijwala-yuy (Sun-down), literally 'sun descends', the place where the sun descends (Montani 2012).

\section{Celestial objects from a Wichi perspective}

When starting to investigate how the Wichi understand what we see as celestial objects, we found a variety of myths that refer to them. This 'variety' is not an obstacle for the analysis; it simply has to be considered along with the other narratives related to the same celestial object in order to understand or explain its meaning. Some of these narratives have been included below to account for the symbolic wealth 
of the sky. In addition, these myths often enable us to understand or link some natural or everyday facts in the communities. It should be noted that the narratives and knowledge described here relate to oral narratives that vary not only within the same village but across the numerous Wichi communities spread throughout the Chaco region. Narrative development changes with the context in which the story is told. In addition, there is a wide range of differences in the way of naming and/or arranging some asterisms in the sky. This fact makes our research all the more interesting and explains the flexibility of these narratives, which on many occasions are another way of expressing the changes undergone by the Wichi with the passing of time.

Stars (kates) in general are seen as women. In fact, the current (terrestrial) women descend from them. The Wichi assert that star excrements may be found in the earth. Among some Guaycurú, Toba or Mocoví groups, shooting stars are regarded as star-dung. The fungi the Wichi associate with star excrements are the 'Gasteromycetes, especially of the genus Geastrum' (Suárez 2012). Among some Wichi, it is believed that shooting stars are 'devils' which go to the graves of those who have died recently, in order to eat them.

The narratives, myths or knowledge included below relate to the sky and 'its inhabitants'.

The Sun is considered to be a male character, the Moon's eldest brother (Braunstein 1989; Lehmann-Nitsche 1924), while in the myths compiled by Wilbert \& Simoneau (1982) they are not brothers but friends. It is also known as tuh-hinnó or man-eater and is seen as a voracious and anthropophagous being (Califano \& Dasso 1988). In Dasso's work (1989), the transformation of certain primeval outsiders that dominated the fire in the Sun accounts for the origin of the 'east'. Also, the Sun is here presented as the father of the Star-Woman that devours his daughter's husband, his son-in-law (Califano \& Dasso 1988).

In the past, the Sun underwent a transformation, first losing part of his power and heat to then recover them. This not only relates 
to the regular seasonal changes observed by the Wichi but also to the origin of time and of the history of the Wichi people, when the light separated from the darkness, and the day from the night (Dasso 1989). For her part, Barúa (2001) also presents the Sun as the Moon's brother. It is said to be a benevolent being, a life-giver but also an insatiable and voracious being. The aim is to show the Sun's mixed characteristics, a powerful being close to Wichi features and nature, and at the same time dangerous and worthy of respect. Again, the need is felt to treat these beings in a cautious and equitable manner to ensure Wichi subsistence.

The Moon is a male character and the Sun's youngest brother or friend. The moon cycle is relevant to Wichi life - a new or crescent moon is a good time to sow, prepare fermented drinks like aloja or chicha, stage attack, or go to war. On the other hand, a waning moon or 'dead' moon is not a good time to undertake any activity (Lehmann-Nitsche 1924). During new or crescent moon, they would dance to the beat of their drums (pim pim). Dancers wore "pendants of metal, hoofs and so on" (Métraux 1939:9).

Moon was created by a powerful mythical being from a mixture of earth and old women who lived in heaven (Dasso 1989). He is meant to be the father of all men after having sexual intercourse with a woman. Also, he is the origin of menstruation in women; hence, the lunar and menstrual cycles are synchronized (Wilbert \& Simoneau 1982). Barúa (2001) states that the Moon is associated with fertility but also with death and transformation. In general, the Moon or Wela is characterised by his sexual appearance, which is especially highlighted as his extraordinary member could kill the woman he had sexual intercourse with. This event once unleashed the revenge of the first women and forced Moon to flee Earth (Mashnshnek 1973).

In the 1930s, Alfred Métraux (1935 and 1939) worked among some Wichi groups, and he was told that moon eclipses occur because a feline-like spirit attacks the moon. The moon tries to defend himself with very feeble weapons and the feline begins to win the battle and to 
eat the moon, which becomes red, bleeding, and with torn flesh. But then the moon starts to act with renewed vigour, uses more powerful weapons and, finally, manages to fend off the attack of the feline that attempted to devour him. At times, the same spirit tries to do likewise with the sun, but as he has sturdier weapons he manages to repel the attacks more easily than the moon (Métraux 1935). Eclipses are negative events to the Wichi, a sign of misfortune, disease or death. In former times, during an eclipse, the Wichi gathered and prayed for the eclipse to end, banging on and making noise with various objects (Braunstein 1989; Lehmann-Nitsche 1924).

Venus is of great significance for the Wichi's conception. Venus is given different names if seen in the morning or in the evening. When seen as the 'morning star' it is called Ihwála wú, which describes Venus' action at dawn - 'it makes day'. When seen at sunset, it is known as Katés Lukwetáh (Potbellied Star), 'The Star-Woman' (Braunstein 1989; Lehmann-Nitsche 1924).

Venus has a leading role in the star-woman myth (Braunstein 1989; Gómez 2008, 2009; Wilbert \& Simoneau 1982). A Wichi man, who had initially been despised by his community, has a love relationship with the star-woman. As a result of this relationship, the man becomes attractive for the rest of the women and, thanks to the star-woman's knowledge, harvests abound in times of scarcity. Finally, the relationship ends tragically because, after the escape of his wife (The Star-Woman [Venus]) to the sky, the man pursues her and dies, since the sky is not a place to live for the men.

The grandchildren asterism is formed by Zeta1 and Zeta2 Scorpii, and represents two children, the eldest and the youngest brother (Braunstein 1989, Lehmann-Nitsche 1924). These children might be hunting the cosmic lesser rhea (Rhea americana) or ñandu, while two stars of Sagittarius would represent their parents (Lehmann-Nitsche 1924). The ñandí or suri, Lesser Rhea (Rhea amerinaca), is a flightless bird similar to the ostrich (Struthio camelus), they both have only three toes on each foot but the Lesser Rhea is smaller. 
There are two related asterisms - the Coalsack nebula corresponding to the male suri, and an asterism formed by stars of the Scorpius and Ara constellations for the female and chicks (Lehmann-Nitsche 1924).

The yulo is a large bird similar to a stork. Lehmann-Nitsche's work (1924) describes the existence of the Great Yulo, a mythological bird, the master of the rain, which has a stellar link with an asterism made up of the Pleiades (head), the Hyades (body), and the Belt of Orion (legs/feet). On the other hand, other researchers claim that in the Wichi conception of the sky they have found no trace of this asterism or of the relationship of this mythical animal with rain (Braunstein 1989).

The story of the Southern Cross relates to two brothers, which probably correspond to those mentioned in 'The Grandchild' narrative. Their dog climbed up to the sky chasing a flock of ñandu or suri (Rhea americana), represented in the Southern Cross. Then, one of the brothers took the other on his shoulders and they both ascended to get the dog. First they went westwards, but as they got near, the dog kept going south. And as Métraux describes: "Since then, the same thing always happens. In the summertime, the two brothers go south around three in the morning, but in winter, they are seen in the sky at five o'clock in the afternoon" (Métraux 1935:63). Another version of the same myth places the brothers in another position in the sky, in the Coalsack nebula (Métraux 1939:15).

On the other hand, as is also the case among the Toba in western Formosa Province, a rabbit warren is seen in the sky. Additionally, the master of all the armadillos, which removed the first women from Earth (Métraux 1935), is observed. These similarities had been noted by Tomasini (1969/70).

The Milky Way has been subject to different interpretations; one sees it as path (Lehmann-Nitsche 1924, Métraux 1935), the 'path of the suri' (Braunstein 1989). Another, as a river, particularly in connection with the Bermejo River in the Gran Chaco region (Lehmann-Nitsche 
1924, Braunstein 1989). It is also conceived as the smoke remaining after a portion of the sky was burnt to open up a straight path. What is currently seen across the sky are the ashes and the smoke left in the way behind the fire (Métraux 1935:33).

The Pleiades appear as a complete stellar family, where the Moon is the father and Venus, the mother. This family has many younger siblings, who grow up and, as they become adults, move to the border of the asterism. When they attain a stage of maturity, they part with the family and fall down to Earth. Once they reach the world, they impregnate the soil, thus favouring plant development, especially the algarroba, the fruit of the white carob tree (Prosopis alba), and the provision of honey, which are key staples in the Wichi diet. The shamans in each community have to undertake an annual journey to the Pleiades to propitiate and encourage this union between the Moon and Venus. On one occasion, the shamans did not set out on time, which sparked off conflict in the family inhabiting the Pleiades. As a result, draughts, poor harvests, and famine hit the community (Barua 2001).

This event is also related to another Wichi mythical construct: the fertility of the Pleiades is associated with plant as well as human fertility. As occurs in other Chaco groups, the origin of women in Wichi mythology is celestial. The first women, the first mothers of the Wichi, descended from the stars. In the beginning, women lived in the sky and came down occasionally to steal food. When the first inhabitants of the Earth saw this, they cut the sky rope and so the women were trapped on earth (Métraux 1935, 1939; Wilbert \& Simoneau 1982; Pérez Diez 1983; Alvarsson 1983; Dasso 1989).

However, this is only one of the numerous versions about this asterism. As mentioned earlier, a myth explains that the Pleiades represent some hunters that remained marooned in the sky after offending an old man or old woman who decided to thus avenge himself/herself (Campana 1913; Métraux 1935, 1939). The Pleiades are also described as part of a larger asterism made up of the Hyades, the 
Sword of Orion, and the Belt of Orion (Lehmann-Nitsche 1924). In another narrative, this asterism is formed when some corzuela deer flee to the sky to escape from danger (Mashnshnek 1973; Califano y Dasso 1984, 1988), although to be more precise the above myth tells how a jaguar, the wife's father, murders his son-in-law, the corzuela deer. This event unleashes revenge as the corzuela's children (and the jaguar's grandchildren) kill their grandfather's children (i.e. their uncles, their mother's brothers). Afterwards, they give the meat obtained to their grandfather, who did not know that he was about to eat his sons. When the jaguar grandfather realises what has happened, he tries to reach his grandchildren but they have already retreated to safety in the sky forming the Patsezlai, the Pleiades (Palmer 2005:277-287). This myth is of great significance as it explains how an asterism is related to a key element in Wichi social organisation - kinship. In his notable investigation conducted among the Wichi of Salta Province (Zlaqatahyi and Lhaka Honhat), John Palmer (2005) provides a detailed analysis of this narrative. As Villar (2007) explains, the issue of the affine's unfavourable position in the uxorilocal domain is thus represented. In other words, the fact that the husband (affine) goes to live in his wife's place of residence together with her entire consanguine family leaves him in a weak position. Thus, the system's own contradictions may be seen in a tragic or grim light as they reveal the conflicts faced by alliance relations even if developed according to Wichi rules. This aspect of social organisation is also associated with the myth of Venus representing the Star-Woman (Gómez 2009).

It is interesting to note two other narratives about the cluster known as Patsezlai and usually represented by the Pleiades. One of the narratives tells how this being can steal the husek (a term that could, in principle, be related to the idea of 'soul', albeit being something much more complex) of infants and children that stare intently at the sky (Suárez 2012:155). On the other hand, Wichi shamans claim that this asterism "makes a sound of children playing" (Palmer 2005:285) when it appears in the sky for the first time. Furthermore, the fact 
that it relates to 'the first appearance of the asterism' might lead us to think that it is associated (as happens in other Chaco groups) with the start of the Wichi yearly cycle.

\section{The Wichi yearly cycle}

The yearly cycle is also linked to the sky and, according to the Wichi perspective, to its related phenomena. This topic has been expounded by several authors (Pérez Diez 1974; Alvarsson 1988), and there is also the work written by Pastor Arenas (2003) among the Wichi-Lhuku'tas. The Wichi communities of western Formosa Province (Argentina) use a variety of terms to name the periods of time that we might compare to 'seasons'. But they also account for shorter cycles within the yearly cycle through other sub-cycles that are associated, for instance, with the ripening of fruit or the iguana's behavior (Arenas 2003:182). However, we would like to especially focus on the yearly cycle in connection with the 'arrival of a new year'. Today, the Wichi talk about the beginning and the end of the year based on a perspective imposed by western society; but the elders have a different viewpoint. Among the Wichi, the time of the year associated with a period of scarcity is known as 'lup or jwiye'til and roughly corresponds to the month of July. It is a time when there is no meat, plants are dry, and water in reservoirs gradually disappears. The term 'lup' describes this situation, although for the elders it means 'year'. As pointed out by Arenas (2003:191), this period of time could have been the 'middle' or the start and finish of a yearly cycle in bygone days. It coincides with the appearance of the Pleiades in the east, shortly before dawn, after remaining invisible for a while. For the Wichi Noctenes (Bolivia), among whom Alvarsson (1982) worked, the beginning of the year occurs with the Pleiades heliacal rising during the winter solstice (in the Southern Hemisphere).

Nowadays, the Wichi use ya'chyep to refer to the period of time corresponding to December. This term is associated with the 
'new year', which is also known as jwa\#a'yu, a season abounding in white carob's fruit (Prosopis alba). Today, December has been incorporated as the 'end of the year' (ya'keyep to:neya'yik), marking the finish to the year and the start of another in the following month (Arenas 2003).

\section{Final considerations}

The sky in the the Wichi culture is a subject that it has not been deeply explored in ethnographic research. At best, it can be found scattered in several investigations, descriptions and mythology related to some asterisms, celestial objects and phenomena that are considered intrinsic to the sky from the point of view Wichi. It is a theme that has often been treated transversely in various ethnographies but it has rarely been deeply analyzed. Although, this task has already begun among the Wichi, especially in the analysis of the Star-Women and its relationship with parenthood and femininity as it is understood by them - as the Wichi understand this term -, there is still much to be done. We have begun this task, but the next step is to get the funds to do field work and continue our investigation in situ with the whole corpus presented in this work already collected.

On the basis of this brief bibliographic compilation, it may be said that the relationship with the celestial plane is manifested through myths and beliefs, and that these narratives are part of the Wichi empirical and practical lore. Therefore, they have a deep influence on Wichi everyday chores and economic activities.

The Wichi territory is vast and, as described above, oral traditions vary even within the same village; there is no unambiguous knowledge. We have attempted to include oral narratives because they are important to display an array of knowledge that should be analysed in its full complexity. There is an interrelation between different natural domains as well as between the manifold beings that populate the Wichi worldview, both those inhabiting the sky and those on earth. 
Based on the research over the literature and the ethnographies made at various periods about the Wichi, they obviously have their own particular asterisms and a particular reading of the sky. Also, this perspective differs from the reading given by the official formal learning and from the readings of other indigenous peoples of the argentine Chaco. It might be added that this view of the sky, like much of their world view, has adapted to the changes that have tried to impose them without losing their own point of view. We see how the changes undergone by these societies are reflected in their beliefs of the sky and how such beliefs have an influence on the knowledge outsiders attempt to impose. An example of this can be noticed in the way that the characters and creatures related to new faiths and religions who reach the places inhabited by the Wichi are incorporated into their 'traditional' beliefs. We believe that this research area promises interesting findings in the future.

After work carried out, we could add that at a deeper level, this is all woven into the fabric of Wichi social organisation and their culture, as briefly discussed in our example of the Pleiades and their relationship with an aspect of kinship. Such a perspective makes research of this type become a fascinating endeavour and highlights the intricacies of its analysis. As we have argued in another article (Gómez 2015), to separate the sky from the rest of the Wichi worldview is something artificial that has more to do with the interests of the researcher than with the cosmic order as would be understood by a Wichi person. In principle, we can say that the sky is linked to other phenomena of everyday Wichi life, related at the same time to aspects of the natural and social order. In the same way, the sky is tied both to 'traditional' cultural aspects and to those symbolic adaptations linked to cultural change.

Although much has been written, we understand there is still a good deal to investigate and that plenty of ethnographic research work should be added to our brief analysis. Any work on cultural astronomy should not only provide information on but also look into 
the changes and continuity of knowledge. In our opinion, it is of paramount importance to keep investigating facts of this kind in order to update the interpretation of the sky and study the related symbolisms.

\section{References}

ALVARSSON, Jan-Åke. 1983. "The origin of Mataco women". Latin American Indian Literatures, 2:167-169.

1988. The Mataco of the Gran Chaco. Upssala: Series in Cultural Anthropology.

ARENAS, Pastor. 2003. Etnografía y Alimentación entre los Toba-Nachilamole\#tek y Wichi-Lhuku'tas del Chaco Central (Argentina). Buenos Aires: Dunken.

BRAUNSTEIN, José.1974. "Dominios y jerarquías en la cosmovisión de los matacos tewokleley". Scripta Ethnologica, 2(2):7-30.

. 1976. "Los wichí. Conceptos y sentimientos de pertenencia grupal de los Mataco". Scripta Ethnologica, 4(1):130-143.

1983. Algunos Rasgos de la Organización Social de los Indígenas del Gran Chaco. Buenos Aires: Serie Trabajos de Etnología Nro. 2, Facultad de Filosofía y Letras.

. 1989. "Astronomía mataca. Revisión crítica de la Mitología Sudamericana V de Roberto Lehmann-Nitsche”. Scripta Ethnologica, 9: 43-60.

. 1993. "Territorio e historia de los Narradores Matacos". Hacia una Nueva Carta Étnica del Gran Chaco, 5:4-74.

BARÚA, Guadalupe. 2001. Semillas de Estrellas. Los nombres entre los Wichí. Buenos Aires: Dunken.

CALIFANO, M. \& DASSO, M. C. 1988. "Diccionario referencial de teofanías wichî". Mitológicas, 3:37-46.

CAMPANA, Doménico Del.1912. "Contributo all'etnografia dei Matacco". Archivio per l'Antropologia e la Etnologia, 43:305-325.

DASSO, María Cristina. 1989. "Las transformaciones del sol y las estrellas en la cosmovisión de los mataco (grupo tachóhnai)”. Scripta Ethnologica, 9:19-42.

. 1990. "Lectura simbólica de los textos bíblicos desde la perspectiva wichí: el exceso de significación”. Scripta Ethnológica, 10:21 - 25.

GÓMEZ, Cecilia Paula. 2008. "Venus and the Star Woman". Archaeologia Baltica, 10:25-28.

2009. Parentesco y representación estelar de la mujer entre los Wichí del Gran Chaco. Trabajo presentado en $\mathrm{el} \mathrm{VI}^{\circ}$ Congreso de Americanistas. Actas del VI Congreso de Americanistas: 205-219. Buenos Ayres. 
GÓMEZ, Cecilia Paula. 2015. "The Sky among the Toba of Western Formosa (Gran Chaco, Argentina)”. In RUGGLES, C. (ed.): Handbook of Archaeoastronomy and Ethnoastronomy, pp. 981-985. New York/ Heilderberg/ Dordrecht/ London: Springer.

LEHMANN-NITSCHE, Roberto. 1924. "La Astronomía de los Matacos”. Revista del Museo de La Plata, 27:253-265.

MASHNSHNEK, Cristina. 1973. "Seres potentes y héroes míticos de los Mataco del Chaco central”. Scripta Ethnologica, 1:105-156.

MÉTRAUX, Alfred. 1935. "El universo y la naturaleza a través de las representaciones míticas de dos tribus salvajes de la Argentina”. Sur, 10:54-70. . 1939. Myths and tales of the Matako Indians. Göteborg: Etnologiska Studies Nro. 9.

MONTANI, Rodrigo. 2012. El mundo de las cosas entre los wichís del Gran Chaco: Un ensayo etnolingüístico. Tesis Doctoral. Córdoba: Universidad Nacional de Córdoba.

PALMER, John. 2005. La Buena Voluntad Wichi. Una espiritualidad indígena. Formosa/Salta: APCD/ CECAZO/ EPRAZOL/ FUNDAPAZ/ Franciscanas Misioneras de María/ Parroquia Nuestra Señora de la Merced/Tepeyac/ Asociana.

PEREZ DIEZ, Andrés. 1974. "Noticia sobre la concepción del ciclo anual entre los matacos del noreste de Salta”. Scripta Ethnológica, 2(1):111-120.

SUÁREZ, María Eugenia. 2012. "Espíritus vinculados con el bosque y sus plantas en el mundo de los wichís del chaco semiárido salteño, Argentina”. In ARENAS, Pastor (ed.): Etnobotánica en Zonas Áridas y Semiáridas del Conosur de Sudamérica, pp. 145 - 178. Buenos Aires: CEFYBO/CONICET.

TOMASINI, Alfredo. 1969/70. "Señores de los animales, constelaciones y espíritus en el bosque en el cosmos mataco-mataguayo". Runa, 12(1-2):427- 443.

VILLAR, Diego. 2007. "Palmer John, La buena voluntad wichí. Una espiritualidad indígena”. Journal de la Société des Américanistes, 93(2):215-223.

WILBERT, J. \& SIMONEAU, K. (eds.). 1982. Folk Literature of the Mataco Indians. Los Angeles: UCLA Latin American Center Publications.

Recebido em fevereiro de 2017.

Aprovado em junho de 2017. 